\title{
Utilization of Jaki Application in Improving Public Services in DKI Jakarta
}

\author{
Farhan Andaru Daffa ${ }^{1, *}$ Satya Budi Nugraha ${ }^{2}$
}

\author{
${ }^{1}$ Department of Geography, Faculty of Social Sciences, Universitas Negeri Semarang \\ ${ }^{2}$ Department of Geography, Faculty of Social Sciences, Universitas Negeri Semarang \\ *Corresponding author. Email: daffaandaru07@gmail.com
}

\begin{abstract}
Jakarta Kini (JAKI) is an application created by the Government of DKI Jakarta to help all people access public services. JAKI is designed to create a smart city that efficiently and effectively makes Jakarta a better and liveable city. Therefore, JAKI presents the features which are expected to make life easier for many people. There is at least 10 (ten) kind of services which could be handled by JAKI, including Jakwarta, Jaklapor, Jaksurvei, Jakpangan, JakISPU, JakSiaga, JakCo, and JakApps. This study aims to analyze the utilization of the JAKI application to improve public services in DKI Jakarta. The research was conducted by spreading a questionnaire to JAKI users in 5 (five) municipalities of DKI Jakarta. The data obtained were analyzed to show which municipalities had the most users of the JAKI application and how the JAKI application helped improve public services by grouping them into five indicators: unhelpful, less helpful, sufficient helpful, helpful, and very helpful.
\end{abstract}

Keywords: JAKI application, public services, DKI Jakarta, smart city.

\section{INTRODUCTION}

A smart city is an excellent step in advancing the city based on information technology and communication [1], [2]. City development with the concept of a smart city has developed in various parts of the world. The advancement of information and communication technology is a huge opportunity to support urban development that is inclusive, adaptive to change, and sustainable [3]-[6]. Technology development in public services based on the smart city concept is the right strategy to solve urban problems. The proper use of technology can make various public services and infrastructure, such as population administration services, education, health, transportation, and others, more efficient and responsive in meeting community needs [7]-[11].

One of the advantages of the Smart City concept is that it can create better livable city planning and development in the future. The Smart City concept is also making government services more quickly implicated in society. Besides, the concept of a Smart City can also make the transportation system more efficient and integrated to increase the mobility of its people. The environment can also be more sustainable because of waste management and more advanced water management. In other words, a smart city will also improve community welfare and improve health services.

The smart city concept is expected to make a smart city with a concept designed for public services to be efficient and effective. As one of the largest metropolitan cities in Indonesia, Jakarta does not want to be left behind in developing the smart city concept. Jakarta Smart City is the smart city concept that can optimize the use of information and communication technology to identify, understand, and control various resources more effectively and efficiently to maximize the public services in DKI Jakarta.

Jakarta Kini (JAKI) application is one of the programs of Jakarta smart city. It is an application created by the Government of DKI Jakarta to help all people access public services [12], [13]. JAKI is designed to create a smart city that efficiently and effectively makes Jakarta a better and liveable city. Therefore, JAKI presents the features which are expected to make life easier for many people. This study aims to analyze the utilization of the JAKI application to improve public services in DKI Jakarta. 


\section{RESEARCH METHOD}

This research uses quantitative research methods. The research was conducted by spreading a questionnaire to JAKI users in 5 (five) municipalities of DKI Jakarta using the google form. Through this method, data was collected for 100 respondents for every municipality of DKI Jakarta. The data obtained were analyzed to show which municipalities had the most users of the JAKI application and how the JAKI application helped improve public services by grouping them into five indicators: unhelpful, less helpful, sufficient helpful, helpful, and very helpful.

\section{RESULT AND DISCUSSION}

\subsection{JAKI Application and Features}

The JAKI application was developed to answer the needs of today's society for information and technology in public services. There are at least ten (10) kinds of services which could be handled by JAKI, including Jaklapor, JakRespons, Jakwarta, Jakpangan, JakWifi, JakPantau, JakSurvei, JakISPU, JakSiaga, JakPenda. Each feature in the JAKI application has a different function, as described in table 1.

Table 1. Features Description and Function of JAKI Application

\begin{tabular}{|c|c|c|}
\hline No & Features & Description \\
\hline 1 & JAKLAPOR & $\begin{array}{l}\text { The people of DKI Jakarta can also report the problems in Jakarta } \\
\text { through JAKI. The reporting system in JAKI is based on geo-tagging and } \\
\text { is integrated with the rapid community response }\end{array}$ \\
\hline 2 & JAKRESPONS & $\begin{array}{l}\text { Reports about problems reported by residents through JAKI can be } \\
\text { monitored for the follow-up process through the JakRespons feature. }\end{array}$ \\
\hline 3 & JAKWARTA & $\begin{array}{l}\text { JAKI presents official news directly from the Regional Government. The } \\
\text { information that the public gets is published directly from the provincial } \\
\text { government of DKI Jakarta. The information presented is also in geo- } \\
\text { tagging technology or geographic tagging. It means that residents will be } \\
\text { notified if they are around the news incident area. }\end{array}$ \\
\hline 4 & JAKPANGAN & $\begin{array}{l}\text { The list of market commodity prices is now presented briefly in the } \\
\text { JakPangan feature. Without having to come directly to the market, the } \\
\text { public can calculate their food needs before buying. }\end{array}$ \\
\hline 5 & JAKWIFI & $\begin{array}{l}\text { This JakWifi feature supports the internet network for some areas in DKI } \\
\text { Jakarta. This feature will make it easier for Jakartans to find } 4,956 \text { free } \\
\text { public Wi-Fi points. }\end{array}$ \\
\hline 6 & JAKPANTAU & $\begin{array}{l}\text { Through the JakPantau feature, the public of Jakarta can prepare } \\
\text { themselves better when it rains heavily. JAKI users can access the latest } \\
\text { information about river flows and conditions of floodgates in Jakarta. }\end{array}$ \\
\hline 7 & $\begin{array}{l}\text { JAKSURVEI } \\
\text { JAE= }\end{array}$ & $\begin{array}{l}\text { The JakSurvei feature provides an evaluation room for residents who } \\
\text { wish to assess the performance of public services provided by the Jakarta } \\
\text { government. }\end{array}$ \\
\hline
\end{tabular}




\begin{tabular}{|l|l|l|}
\hline No & Features & $\begin{array}{l}\text { Description } \\
\text { The JakISPU feature presents an Air Pollution Standard Index and is } \\
\text { integrated with the air sensors belonging to the Jakarta Environment } \\
\text { Agency in real-time. }\end{array}$ \\
\hline 9 & JAKISPU & $\begin{array}{l}\text { By installing the JAKI, residents of DKI Jakarta automatically have } \\
\text { significant numbers during critical situations, such as Jakarta Alert 112, } \\
\text { the SAR team, the fire department, and others. }\end{array}$ \\
\hline 10 & JAKSIAGA & \begin{tabular}{l} 
From the JakPenda feature, users can check taxes obligation. \\
\hline
\end{tabular} \\
\hline
\end{tabular}

(source: JAKI application)

\subsection{User Opinion on the Benefits of the JAKI Application}

Based on data obtained from questionnaires about the use of the JAKI application. Information was obtained from five municipalities in DKI Jakarta, which showed a relatively high number of JAKI application users (Table 2).

Table 2. Distribution of JAKI Application Users in DKI Jakarta

\begin{tabular}{|c|c|}
\hline Municipalities & Total Users \\
\hline Central Jakarta & 75 \\
\hline East Jakarta & 70 \\
\hline North Jakarta & 64 \\
South Jakarta & 90 \\
West Jakarta & 87 \\
\hline
\end{tabular}

(source: research result, 2021)

From table 2, we can know the result by spreading 100 questionnaires to every 5 (five) municipalities of DKI Jakarta. The result shows that the South Jakarta Municipality is the municipality with the most users of the JAKI application. There are $90 \%$ of people of South Jakarta who know and utilize the JAKI Application. Meanwhile, the North Jakarta Municipality is the municipality with the minor users of the JAKI application. There are only $64 \%$ of people who know and widely use the JAKI application.

According to Capdevilla and Zarlenga [8], the critical point in developing the concept of a smart city is not only oriented to the top-down model of implementing an application in the context of public services. However, it is more about fostering bottom-up community initiatives in utilizing existing media or applications to meet their needs and provide input to the government. In this context, the varying conditions of using the JAKI application in the five municipalities in DKI Jakarta also show that disseminating information is still not evenly distributed and the possibility of differences in digital literacy skills of residents in each municipal area.

If we see the human development index (HDI) in DKI Jakarta, the HDI score in South Jakarta is the highest. In addition, there are many office complexes in South Jakarta which could represent a higher level of population structure and literacy. Meanwhile, North Jakarta has the lowest HDI score compared to other municipalities. Furthermore, suppose we see the condition in North Jakarta Municipality. In that case, there are many slum area concentrations, representing the low level of technological literacy and lower awareness in the use of technology.

As for the level of usefulness of the JAKI application in supporting the improvement of public services, it was acknowledged by more than half of the public by stating that the application was in the "beneficial" and "helpful" category (Table 3). From table 3, we can see the result that the JAKI application is helping to improve public services, and JakWifi is the most favorite feature in the JAKI application. JakWIFI is a program to improve the quality of public services of free $\mathrm{Wi}-\mathrm{Fi}$ in some areas that are not covered by free internet services. In the current pandemic situation, not surprising that this feature is a favorite because many people (especially students) are helped by utilizing public Wi-Fi in carrying out various activities (studying or working online). 
Table 3. Community Perspective on the Benefits of the JAKI Application

\begin{tabular}{|c|c|}
\hline Indicator & Percentage (\%) \\
\hline Very Helpful & 47 \\
\hline Helpful & 33 \\
\hline Sufficient Helpful & 16.2 \\
\hline Less Helpful & 3.8 \\
\hline Unhelpful & - \\
\hline
\end{tabular}

(source: research result, 2021)

Optimizing the use of information and communication technology is proven to improve public services. It will have a good impact on the benefits obtained by the community. The development of the Jakarta Smart City concept can be an adaptive solution to change and can answer the challenges of today's society who are arguably included in the category 5.0 society. Especially in this covid-19 pandemic situation, people must be good at managing mobility to maintain their health and safety. The JAKI application can be an example for other cities in Indonesia that will implement the smart city concept in managing their city and urban areas.

\section{CONCLUSION}

The JAKI application users are spread relatively even in five municipalities in DKI Jakarta. South Jakarta is the region with the most users, while North Jakarta is the region with the least number of users. The public acknowledges that the JAKI application is beneficial for improving public services in DKI Jakarta. The various features that exist in the JAKI application can represent the needs of today's society. However, development efforts must continue to be made to expand the public services provided and their benefits for the people of DKI Jakarta.

\section{AUTHORS' CONTRIBUTIONS}

Farhan Andaru Daffa, as the first author, is responsible for analysing research data and compiling draft articles. Satya Budi Nugraha as the second author, assisted in reviewing the literature and perfecting articles' preparation and grammar.

\section{ACKNOWLEDGMENTS}

The author would like to thank all those who have supported the implementation of this research, especially the Faculty of Social Sciences, Universitas Negeri Semarang, as the international conference organizer (the 6th ICESS).

\section{REFERENCES}

[1] V. Albino and R. Dangelico, "Smart Cities: Definitions, Dimensions, Performance, and Initiatives," J. Urban Technol., vol. 22, no. 1, pp. 3-21, Apr. 2015.

[2] M. M. Rathore, A. Ahmad, A. Paul, and S. Rho, "Urban planning and building smart cities based on the Internet of Things using Big Data analytics," Comput. Networks, vol. 101, no. 2016, pp. 63-80, 2016, DOI: 10.1016/j.comnet.2015.12.023.

[3] T. Bakıcı, E. Almirall, and J. Wareham, "A Smart City Initiative: The Case of Barcelona," J. Knowl. Econ., vol. 4, no. 2, pp. 135-148, 2013, DOI: 10.1007/s13132-012-0084-9.

[4] R. E. Hall, "The Vision of A Smart City," in Proceeding of the 2nd International Life Extension Technology Workshop, 2000, pp. 1-6.

[5] M. Angelidou, "Smart city policies: A spatial approach," Cities, vol. 41, no. September, pp. S3S11, 2014, DOI: 10.1016/j.cities.2014.06.007.

[6] T. hoon Kim, C. Ramos, and S. Mohammed, "Smart City and IoT," Futur. Gener. Comput. Syst., vol. 76, no. July 2014, pp. 159-162, 2017, DOI: 10.1016/j.future.2017.03.034.

[7] S. Alawadhi et al., "Building Understanding of Smart City Initiatives," E Gov., pp. 40-53, 2012, DOI: 10.1007/978-3-642-33489-4_4.

[8] I. Capdevila and M. I. Zarlenga, "Smart city or smart citizens? The Barcelona case," J. Strateg. Manag., vol. 8, no. 3, pp. 266-282, 2015, doi: 10.1108/JSMA-03-2015-0030.

[9] K. Su, J. Li, and H. Fu, "Smart city and the applications," in International Conference on Electronics, Communications, and Control (ICECC), 2011, pp. 1028-1031, DOI: 10.1109/ICECC.2011.6066743.

[10] A. Hasibuan and O. K. Sulaiman, "Smart City, Konsep Kota Cerdas Sebagai Alternatif Penyelesaian Masalah Perkotaan Kabupaten/Kota, Di Kota-Kota Besar Provinsi Sumatera Utara (Smart City, the concept of a smart city as an alternative solution to urban problems in districts/cities, in big cities of North Sumatra Province)," Bul. Utama Tek., vol. 14, no. 2, pp. 127-135, 2019.

[11] A. P. Cahyani, S. Ode, and D. M. Herawati, "Penerapan Kota Cerdas melalui Citizen Relation Management dalam Pelayanan Publik (Application of Smart Cities through Citizen Relations Management in Public Services)," J. Polit. Issues, 
vol. 1, no. 2, pp. 125-133, 2020, doi: 10.33019/jpi.v1i2.15.

[12] D. Andriyanto, F. Said, F. Titiani, and E. Erni, "Analisis Kesuksesan Aplikasi Jakarta Kini (JAKI) Menggunakan Model Delone and McLean (Analysis of the Success of the Jakarta Present (JAKI) Application Using the Delone and McLean Model)," Paradig. - J. Komput. dan Inform., vol. 23, no. 1, pp. 43-48, 2021, doi: 10.31294/p.v23i1.10018.

[13] A. M. R. Abrizal and A. B. Sudarsono, "Komunikasi Humas Pemprov DKI Jakarta dalam Menangani Pengelolaan Aduan Masyarakat pada Aplikasi JAKI (DKI Jakarta Provincial Government Public Relations Communication in Handling Public Complaint Management on the JAKI Application)," J. IKOM Usn., vol. 2, pp. 113, 2021. 